\title{
PERTUMBUHAN DAN PODUKSI JAGUNG PULUT PADA SISTEM PERTANIAN TERPADU DI LAHAN KERING BERBASIS ALLEY CROPPING
}

\section{GLUTINOUS PRODUCTION IN INTEGRATED FARMING SYSTEMS IN DRY LAND BASED ON ALLEY CROPPING}

\author{
Sukmawati \\ Prodi Agroteknologi Fakultas Pertanian Peternakan dan Perikanan Universitas Muhammadiyah \\ Parepare
}

Korespondensi: Sukmakuuh76@gmail.com

\begin{abstract}
ABSTRAK
Pengembangan jagung yang mengarah pada lahan kering, memerlukan teknologi pertanian yang ramah lingkungan, agar produktivitasnya dapat berkelanjutan. Alley cropping merupakan salah satu teknologi budidaya yang mampu meningkatkan kesuburan tanah dan memperbaiki degradasi lahan. Penelitian ini bertujuan untuk mengkaji pertumbuhan dan produksi jagung pulut pada empat sistem budidaya, yakni monokultur, tanaman berganda, alley cropping dan agrosilvopastura. Percobaan lapangan dilakukan untuk menguji parameter pertumbuhan dan produksi tanaman jagung, yakni tinggi tanaman, jumlah daun, anjang tongkol, diameter tongkol, berat tongkol berklobot segar dan berat tongkol tanpa klobot. Data dianalisis menggunakan program Excel dan uji lanjut BNT. Hasil peneltian menunjukan bahwa keempat sistem budidaya belum memberikan pengaruh secara signifikan pada fase pertumbuhan tanaman. Pengaruh signifikan terlihat pada fase produksi, dimana sistem agrosilvopastura memberikan hasil terbaik terhadap berat tongkol berklobot segar (263 g) dan berat tongkol tanpa klobot (150 g) dan tidak berbeda nyata dengan alley croping (240 g;135 g). Hasil penelitian ini membuktikan produktivitas jagung dapat ditingkatkan di lahan kering melalui penyiapan lahan konservasi agrosivopasture berbasis alley cropping.
\end{abstract}

Kata kunci: Hedgerow, konservasi, legum, ruminansia, serealia

\begin{abstract}
Corn development that leads to dry land requires environmentally friendly agricultural technology, so that its productivity can be sustainable. Alley cropping is a cultivation technology that can increase soil fertility and improve land degradation. The aim of this research was to study the growth and production of pulut maize in four cultivation systems, namely monoculture, multiple cropping, alley cropping and agrosilvopastura. Field experiments were carried out to test the parameters of growth and production of corn plants, namely plant height, number of leaves, length of the cob, diameter of the cob, weight of fresh cob and weight of cob without cob. The data were analyzed using the Excel program and the BNT follow-up test. The results of the research show that the four cultivation systems have not had a significant effect on the plant growth phase.
\end{abstract}


Significant effect was seen in the production phase, where the agrosilvopasture system gave the best results on the weight of fresh green cobs (263 g) and weight of cobs without husks (150 g) and was not significantly different from that of alley cropping ( $240 \mathrm{~g} ; 135 \mathrm{~g})$. The results of this study prove that maize productivity can be increased in dry land through the preparation of agrosivopasture conservation areas based on alley cropping.

Keywords: Hedgerow, conservation, legumes, ruminants, cereals

\section{PENDAHULUAN}

Saat ini profil pertanian lahan kering masih diwarnai produktivitas yang rendah. Ketidakepatan dalam peruntukan lahan untuk tanaman, penggunaan pola tanam, pengolahan tanah, penggunaan pupuk kimia pada kenyataanya menurungkan produkivitas lahan. Hal ini terjadi karena proses degradasi terjadi lebih besar dari upaya konservasi sehingga membatasi pertumbuhan dan produksi tanaman. Sebagai komuditas andalan pertanian lahan kering, jagung hanya mampu menghasilkan produktivitas rata-rata 6,4/ha dari potensi produksi yang bisa mencapai 13 ton/ha (Nurmiaty et al., 2019). Pola tanam monocropping telah menghancurkan keanekaragaman tanaman sehingga membuat efek buruk pada agroekosistem (Vittal et al., 2003). Pengembangan lahan pangan yang mengarah pada lahan kering, memerlukan teknologi pertanian yang ramah lingkungan, agar produktivitasnya dapat berkelanjutan (Ogunlana et al., 2010).

Alley cropping merupakan salah sistem pertanian terpadu berkelanjutan yang dapat diterapkan secara intensifikasi tanpa periode bera. Penanaman tanaman legum dengan pertumbuhan yang cepat dalam bentuk barisan diantara tanaman budidaya dengan jarak barisan 4-5 meter. Tanaman dipangkas secara berkala dan digunakan sebagai pupuk hijau ataupun pakan ternak (Wolz \& Delucia, 2018). Sistem alley cropping menggabungkan banyak kegiatan pertanian, yaitu produksi tanaman, peternakan, penanaman pohon, dan pengelolaan tanah (Ogunlana et al., 2010), sehingga layak secara ekonomi, diterima secara sosial dan ramah lingkungan (Manyong et al., 1999) dengan meniru proses alami dalam peremajaan hutan (Ogunlana et al., 2010). Selain itu, mampu mengurangi erosi dan meningkatkan kesuburan tanah (Lucila Lapar et al., 1999), sehingga dapat memperbaiki tanah terdegradasi.

Mekanisme yang terjadi dalam sistem alley cropping adalah pohon legum diinokulasi oleh bakteri rhizobium, sehingga mampu mengikat nitrogen dari atmosfer. Biomassa yang dihasilkan oleh pohon legum dapat menjadi sumber bahan organik sehingga tanaman lain dapat menyerap nitrogen dari jaringan tanaman legum tersebut. Selain itu perakaran pohon legum yang dalam 
menjadi jaring mengikat hara pada lipsan bawah tanah. Dengan demikian penerapan sistem alley cropping dapat meremajakan lahan pertanian secara alami tanpa proses pemberaan, karena dapat meningkatkan bahan organik tanah adalah 4 sampai 7\% (Seiter et al., 1999).

Oleh karena itu, sistem alley cropping dapat diterapkan pada pertanaman jagung khususnya pada lahan kering dengan topografi miring. Menurut (Efendi, 2009) penanaman jagung di lahan kering harus dikelola secara tepat salah satunya adalah dengan penyiapan lahan konservasi agar lahan tersebut dapat digunakan secara berkelanjutan.. Pengusahaan budi daya jagung yang dapat menutup permukaan tanah sepanjang tahun merupakan tindakan konservasi vegetatif di mana sisa tanaman atau sisa hasil panen dikembalikan sebagai tambahan bahan organik tanah. Bahan organik yang tinggi tidak hanya akan menambah nutrisi tanah setelah melapuk, tetapi juga dapat berperan sebagai penyangga dari pupuk yang diberikan, mengikat air lebih baik dan meningkatkan daya infiltrasi tanah dari curah hujan yang jatuh, mengurangi erosi, aliran permukaan, evaporasi, menurunkan suhu tanah, meningkat kelembaban tanah, dan menekan perkembangan gulma. Terjadi peningkatan produksi jagung manis yang ditanam pada sistem alley cropping dibandingkan pada sistem monokultur (Seiter et al., 1999). Dengan demikian budidaya jagung menggunakan teknologi berbasis alley cropping, menjadi salah satu solusi budidaya tanaman semusim dengan pertimbangan konservasi lahan secara berkelanjutan.

\section{BAHAN DAN METODE}

Penelitian merupakan percobaan lapangan pada lahan kering dengan topografi miring (30\%), jenis tanah alfisol. Lokasi penelitian berada di Desa Tana Karaeng Kecamatan Manuju Kabupaten Gowa Sulawesi Selatan. Berada pada posisi $05^{0} 18^{\prime} 00,5^{\prime \prime}-05^{\circ} 1802,4^{\prime \prime}$ LS dan $119^{0} 366^{\prime} 38,7^{\prime \prime}$ $119^{0} 36^{\prime} 44,0^{\prime \prime} B T$. Jagung pulut komposit varietasURI- digunakan sebagai tanaman indikator. Perlakuan yang diuji adalah sistem pertanian terpadu yang telah diterapkan selama 1 tahun, terdiri dari:1) monokultur jagung, 2) tanaman ganda (jagung+rambutan), 3) alley cropping (gamal+rambutan sebagai tanaman hedgerow), dan 4) agrosilvopasture (gamal, rambutan dan rumput gajah sebagai tanaman hedgeror, ternak kambing PE dan digerster mini). (Gambar 1). Percobaan menggunakan rancangan acak kelompok. Data dianalisis menggunakan EXCEL dan uji lanjut BNT dengan taraf $\alpha=0.05$, apabila terdapat perlakuan yang berpengaruh nyata. 


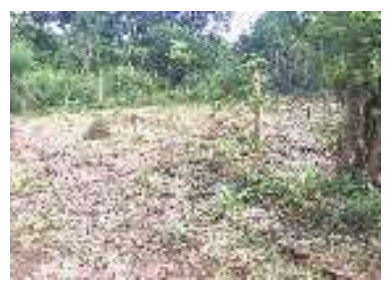

A

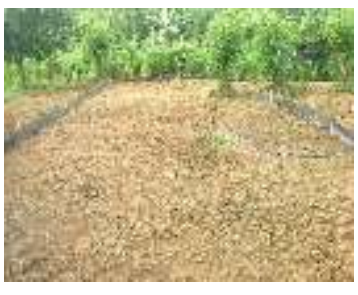

B

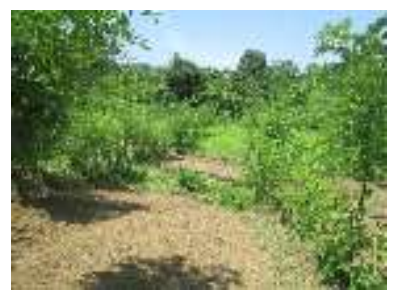

$\mathrm{C}$

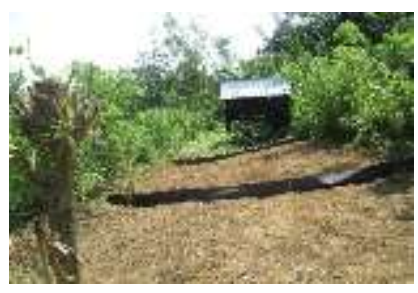

$\mathrm{D}$

Gambar 1. Petak percobaaan penelitian: A) Monokultur, B) tanaman berganda C \}Alley Cropping, D)Agrosilvopastura

\section{HASIL DAN PEMBAHASAN}

\section{Hasil}

\section{Tinggi tanaman dan jumlah daun}

Sistem pertanian terpadu yang diterapakan pada pertanaman jagung pulut dilahan kering miring belum memberikan pengaruh yang nyata pada fase vegetatif tanaman jagung pulut. Hal ini teridentifikasi pada tinggi tanaman dan jumlah daun yang dihasilkan. Walapun demikian ada perbedaan tinggi tanaman maupun jumlah daun yang diamati selama 7 minggu. Semua sistem pertanian menghasilkan tinggi tanaman yang terus bertambah di setiap minggu. Namun demikian pertambahan tinggi jagung pada sistem alley cropping lebih tinggi, yakni $156.38 \mathrm{~cm}$ ). Peningkatan tinggi tanaman mulai pada minggu ke-2 hingga minggu ke-7. Hasil ini tidak berbedah jauh pada sistem agrosivopastura, yakni 155,52 cm. Akan tetapi cukup berbeda dengan sistem tanam ganda yakni 141.30 dan monokultur $134.55 \mathrm{~cm}$ (Gambar 2). Hal yang sama terjadi pada pertambahan jumlah daun pada minggu ke-7, dimana sistem alley cropping menghasilkan jumlah daun yang lebih banyak dan sama dengan agrosivopastura ( 9 helai). Sedangkan sistem tanaman ganda menghasilkan jumlah daun yang sama dengan monokultur yakni 8 helai. (Gambar 3). 


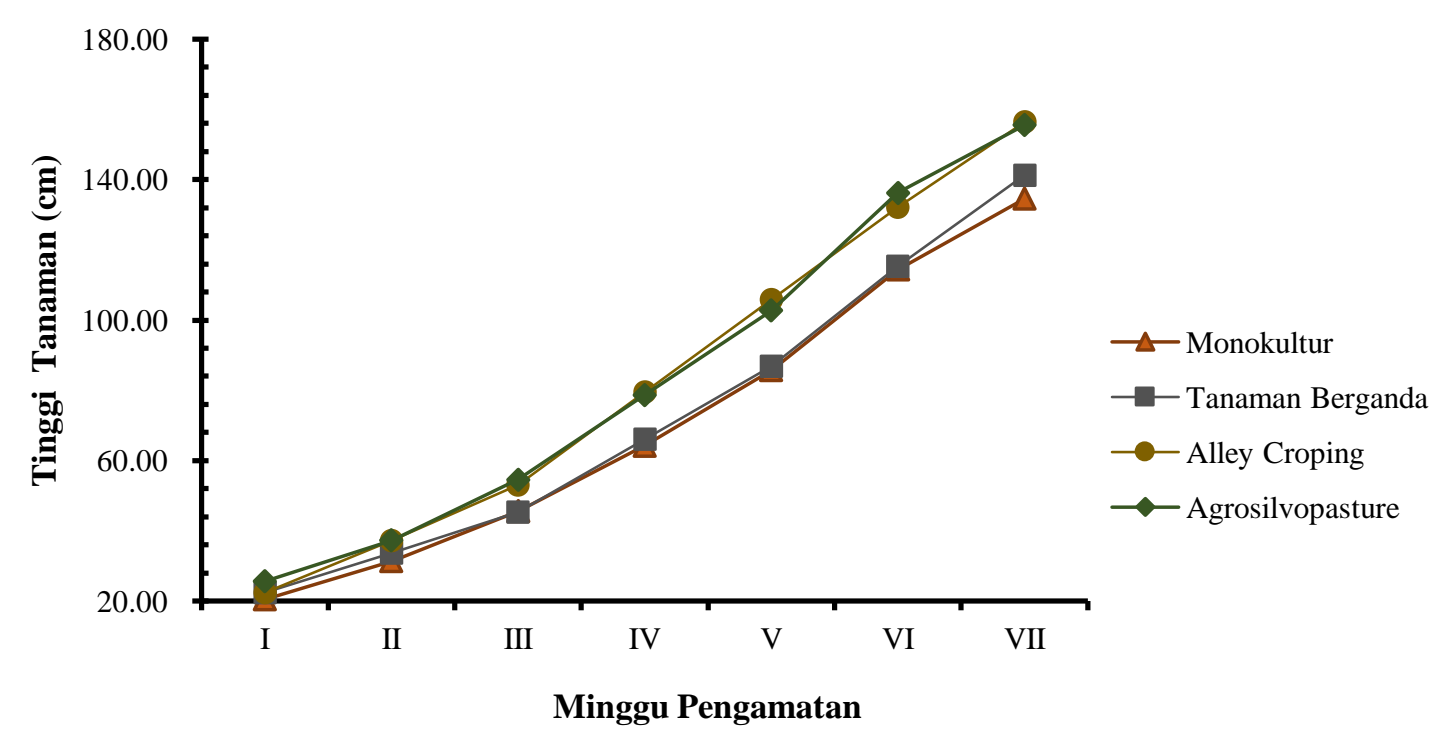

Gambar 2. Rata-rata tinggi tanaman jagung pulut yang ditanam pada berbagai sistem pertanian terpadu di lahan kering

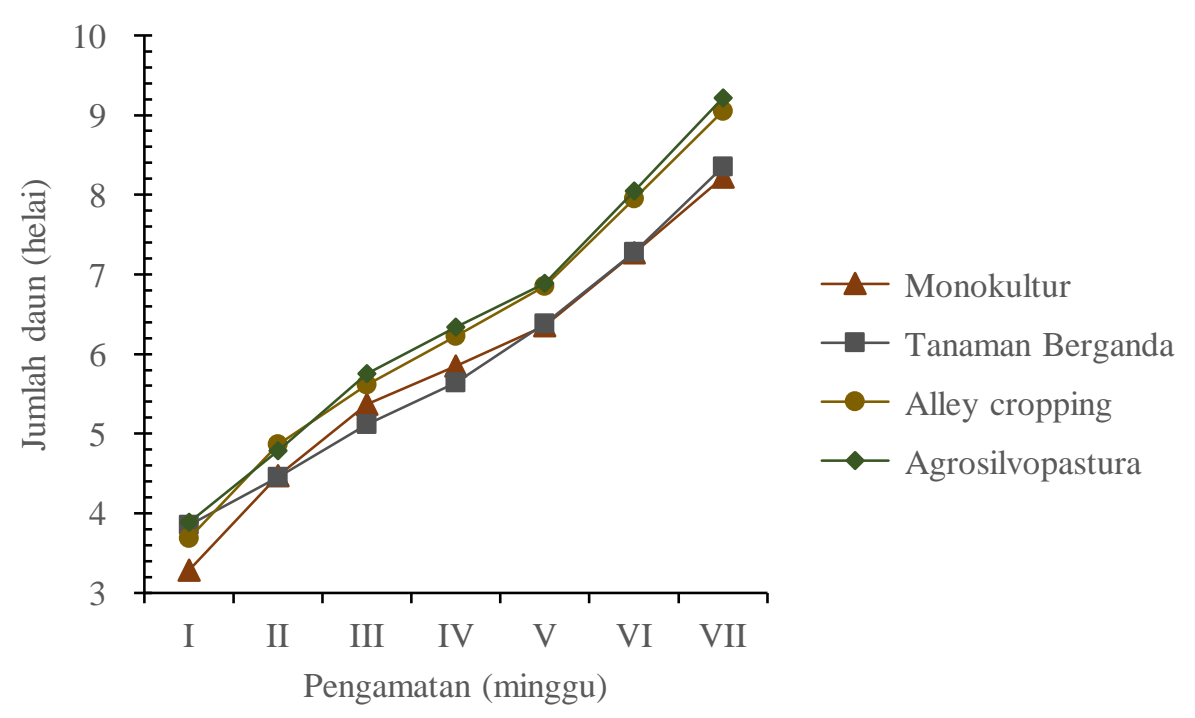

Gambar 3. Rata-rata jumlah daun jagung pulut yang ditanam pada berbagai sistem pertanian terpadu di lahan kering

\section{Panjang tongkol dan Diameter}

Tanaman jagung yang ditanam pada berbagai sistem pertanian terpadu tidak menjukkan hasil yang berbeda nyata pada rata-rata panjang dan diameter tongkol jagung (Gambar 3 dan Gambar 4). Walaupun demikian, sistem agrosilvopastura menghasilkan tongkol jagung pulut yang lebih 
panjang $14.12 \mathrm{~cm}$ dan diameter tongkol jagung yang lebih besar $36.5 \mathrm{~mm}$, dibandingkan pada sistem alley cropping, tanaman berganda dan monokultur.

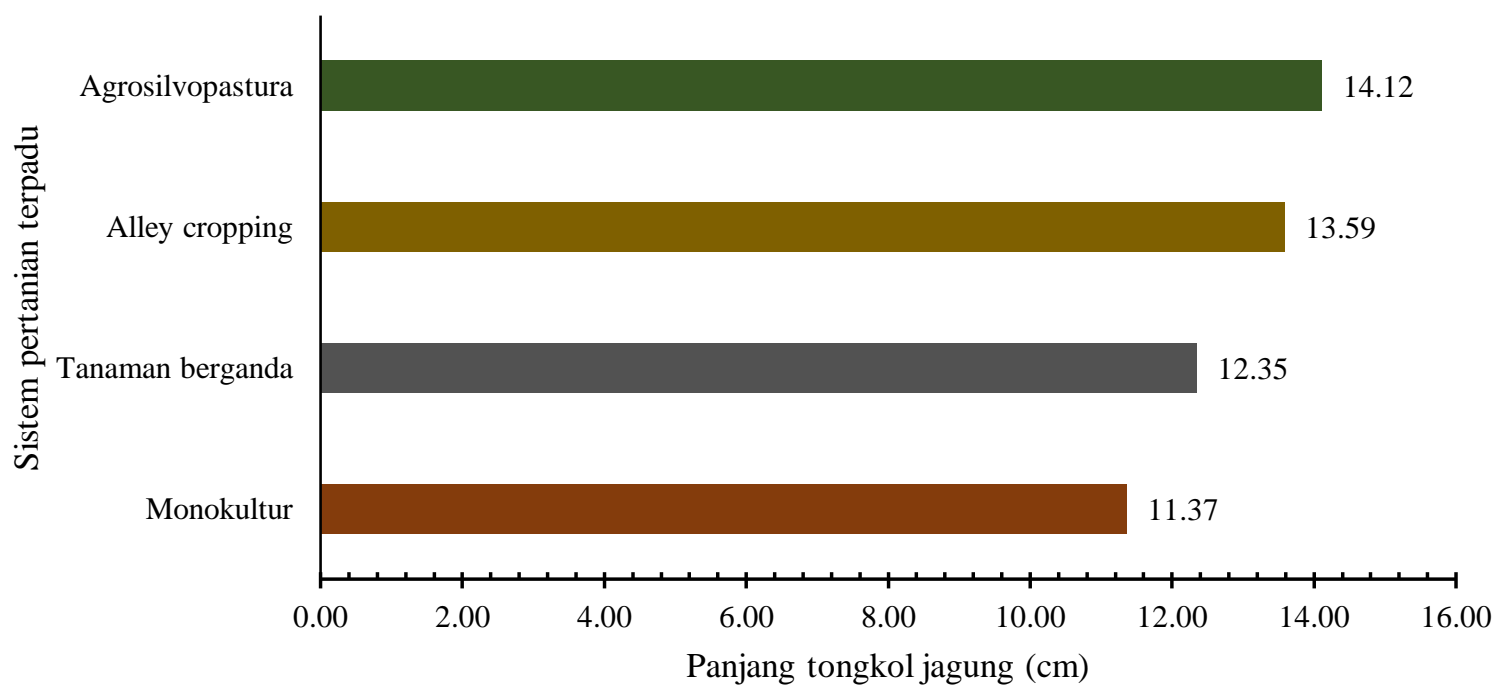

Gambar 4. Rata-rata panjang tongkol jagung pulut yang dihasilkan pada berbagai sistem pertanian di lahan kering

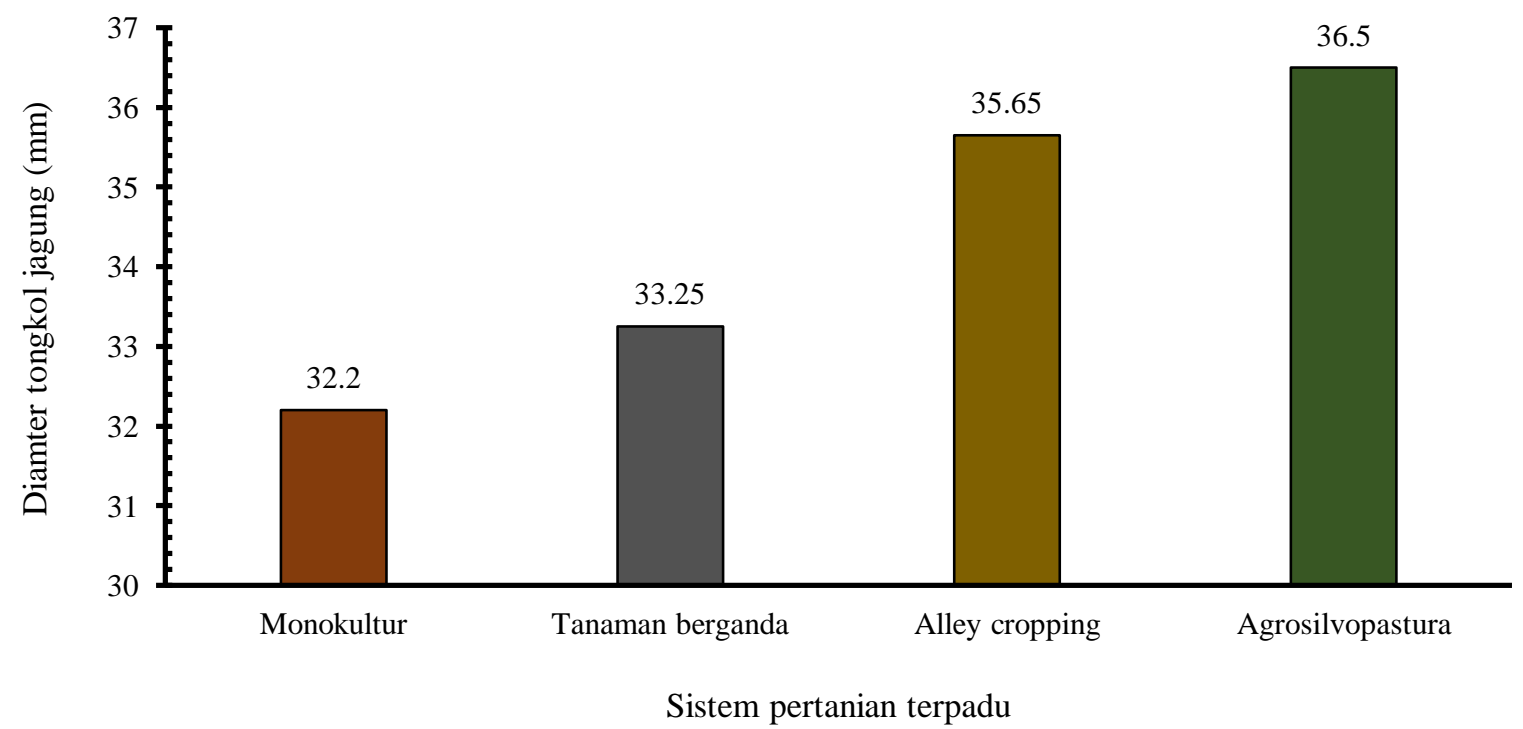

Gambar 5. Rata-rata diameter tongkol jagung pulut yang dihasilkan pada berbagai sistem pertanian di lahan kering

\section{Berat tongkol jagung muda}


Analisis ragam menunjukkan bahwa jenis sistem pertanian terpadu secara signifikan mempengaruhi produksi bobot tongkol berkelobot segar, dan bobot tongkol tanpa kelobot pada taraf $\alpha=0.05$. (Tabel 1). Sistem agrosilvopastura dan alley cropping menghasilkan berangkasan jagung yang lebih berat dan berbeda nyata pada sistem tanaman berganda dan monolkultur. Demikian pula dengan bobot tongkol berkelobot lebih berat dihasilkan pada sistem agrosilvopastura(263 g), namun tidak berbeda nyata dengan alley cropping (240 g). Walaupun demikian hasil ini berbeda nyata dengan tanmana berganda (183 g), bahkan berbeda sangat nyata dengan monokultur (145 g). Setelah kelobot jagung dibuka, hasil yang diperoleh menunjukkan bahwa, tongkol jagung yang dihasilkan pada sistem agrosilvopastura memberikan hasil yang tidak berbeda nyata dengan alley cropping, namun berbeda sangat nyata dengan sistem tanam ganda dan monokultur.

Tabel 1. Produksi jagung pulut pada berbagai sistem pertanian terpadu di lahan kering miring

\begin{tabular}{lcc}
\hline $\begin{array}{c}\text { Sistem Pertanian } \\
\text { Terpadu }\end{array}$ & $\begin{array}{c}\text { Bobot Tongkol } \\
\text { Berkelobot segar }(\mathrm{g})\end{array}$ & $\begin{array}{c}\text { Bobot Tongkol } \\
\text { Tanpa Kelobot }(\mathrm{g})\end{array}$ \\
\hline Monokultur & $145^{\mathrm{c}}$ & $88^{\mathrm{c}}$ \\
Tanaman berganda & $183^{\mathrm{b}}$ & $113^{\mathrm{bc}}$ \\
Alley cropping & $240^{\mathrm{a}}$ & $135^{\mathrm{ab}}$ \\
Agrosilvopastura & $263^{\mathrm{a}}$ & $150^{\mathrm{a}}$ \\
\hline \multicolumn{1}{c}{$\mathrm{NP} \mathrm{BNT}_{0,05}$} & 0.37 & 0.34 \\
\hline
\end{tabular}

\section{Pembahasan}

Secara keseluruhan baik pada fase pertumbuhan maupun fase generatif, sistem agrosilvopastura memberikan hasil terbaik pada tanaman jagung. Meskipun tidak berbeda nyata dengan sistem alley cropping. Hasil penelitian menunjukkan bahwa sistem pertanian berbasis alley cropping lebih efektif untuk diterapkan di lahan kering miring dibandingkan dengan sistem monokultur dan tanaman berganda. Hasil produksi jagung tertinggi pada sistem agrosilvopastura dan sistem alley cropping menunjukkan bahwa tidak terjadi persaingan antara komponen alley yang terdiri dari gamal, rumput gajah maupun tanaman rambutan dengan tanaman jagung pulut sebagai tanaman sela. Penggunaan sistem alley croping dalam budidaya tanaman jagung meningkatkan hasil jagung manis dibandingkan pola tanaman monokultur (Seiter et al., 1999). Pangkasan tanaman gamal yang digunakan sebagai mulsa maupun pakan ternak menjadi sumber nutrisi bagi tanaman jagung. 
Ogunlana et al. (2010) melaporkan bahwa 56.3\% di Ngeri Barat Daya menerapkan sistem alley cropping, dimana 7,1 \% ditujukan sebagai upaya menjaga kesuburan tanah dan 36,3\% menggunakan sebagai sumber pakan ternak sekaligus memeliharan kesuburan tanah.

Dalam penelitian ini, walaupun perlakuan belum menunjukkan pengaruh yang nyata pada fase vegetatif, namun sistem agrosilvopastura dan alley cropping memberikan hasil terbaik terhadap tinggi tanaman dan jumlah daun, jagung pulut (Gambar 2 dan 3). Hasil penelitian belum menghasilkan tinggi tanaman yang maksimal, karena tanaman tertinggi yakni $156.38 \mathrm{~cm}$ pada sistem Alley cropping dan 155,52 $\mathrm{cm}$ pada sistem agrosilvopastura lebih rendah dibandingkan tinggi tanaman maksimal jagung ulut varietas Uri. Jagung Pulut varietas Uri-1 menurut Balai Penelitian dan Pengembangan Pertanian yaitu memiliki tinggi $\pm 177 \mathrm{~cm}$ (Iriayani et al., 2016). Hal ini disebabkan oleh kurangnya pasokan nitrogen yang menjadi kebutuhan tanaman pada vase vekgetatif, karena pupuk dasar hanya menggunakan NPK 15 gr per tanaman. Kekurangan hara N pada suatu tanaman dapat membuat tanaman menjadi kerdil atau pertumbuhannya terhambat (Rahma, 2018), karena nitrogen merupakan salah satu unsur hara yang sangat penting dalam meningkatkan pertumbuhan vegetatif tanaman (Saroni et al., 2016).

Pada sistem agrosilvopastura, sumber nitrogen yang dibutuhkan tanaman dalam fase vegetatif berasal pupuk berasal dari selury hasil fermentasi feces kambing melalui digester. Ini merupakan sumber hara yang tinggi, apalagi ternak kambing diberi pakan dari daun gamal sehingga terjadi akumulasi unsur nitrogen dalam pakan yang terus berakumulasi dalam feces melalui proses fermentasi rumen dan biogas. Variasi kandungan nitrogen tersebut bergantung pada pakan yang dikonsumsi, tingkat kelarutan protein kasar pakan, serta kemampuan ternak untuk memanfaatkan nitrogen asal pakan. Kotoran kambing-domba yang tersusun dari feses, urin dan sisa pakan mengandung nitrogen lebih tinggi daripada yang hanya berasal dari feses (Preston, 2005; Thy, 2007). Kehadiran ternak dalam sistem agrosilvopastura sangat menguntungkan, karena melalui ternak, daun gamal dan tanaman pakan diolah difermentasi dalam rumen menghasilkan feces yang memiliki kandungan unsur hara yang tinggi. Selanjutnya feces difermentasi melalui digester menghasilkan effluent dengan kandungan hara yang lebih berkualitas. Dengan demikian suplai hara tanaman jagung dapat terpenuhi. Tripathi \& Psychas, (1992), melaporkan bahwa Leucaena leucocephala dan Gliricidia sepium sering digunakan dalam sistem alley crooping berbasis ternak, karena mengandung $20 \%$ protein kasar (3.4\% nitrogen) sehingga menghasilkan 
pakan bernutrisi tinggi. Dari produksi feces maupun urin dapat dihasilkan pupuk yang memiliki nilai hara yang tinggi karena diproses melalui fermentasi dalam digester.

Disisi lain, pertumbuhan tanaman jagung juga lebih baik pada sistem alley cropping. Barisan tanaman gamal dan rumput gajah secara fisik mampu mengurangi aliran permukaan dan mempertahankan kandungan bahan organik tanah, walaupun intensitas hujan yang tinggi. Disisi lain sumber pupuk pada sistem alley cropping berasal dari pangkasan gamal yang digunakan sebagai mulsa sekaligus pupuk hijau bagi tanaman jagung. Pemangkasan daun gamal merupakan sumber nitrogen secara rutin digunakan sebagai penamah bahan organik (Gambar 6) sekaligus dapat mengurangi evaporasi. Selain itu mengurangi persaingan tanaman dalam pemanfaatan sinar matahari. Mulsa pada permukaan tanah berfungsi mempertahankan kelembaban tanah, menurunkan evaporasi air tanah dan meningkatakan infiltrasi air ke dalam tanah sehingga mempengaruhi produksi tanaman jagung (Efendi, 2009). Hal terpenting dalam sistem alley croping adalah pengaturan jarak tanam sehingga semua komponen tanaman tidak saling mengganggu satu sama lain. Justru terjadi efisiensi serapan hara karena adanya perbedaan perakaran, karena unsur hara yang terlindi kelapisan terdalam dapat dijangkau oleh tanaman gamal untuk selanjutnya disimpan dalam jaringannya, kemudian seresah dapat dimanfaatkan oleh tanaman jagung.
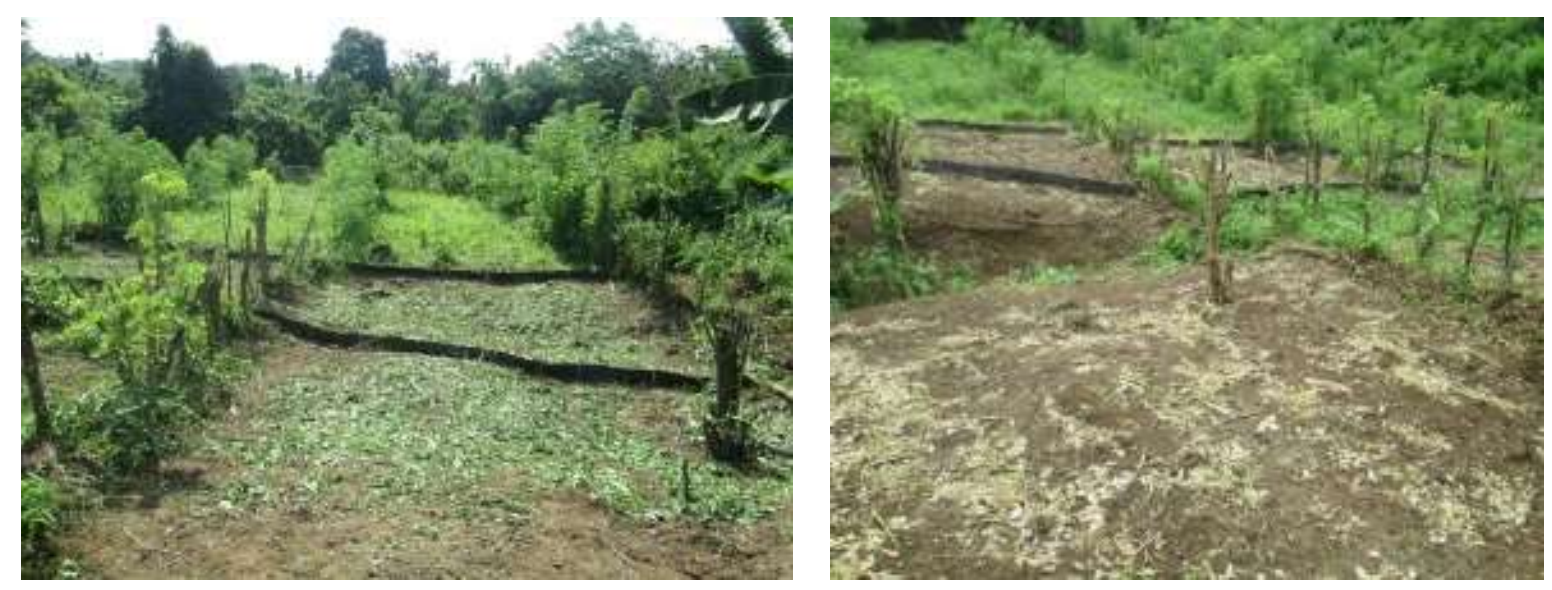

Gambar 6. Daun gamal sebagai mulsa pada sistem alley cropping

Perlakuan sistem pertanian terpadu pada budidaya jagung pulut, secara signifakan baru terindikasi pada fase generatif, yakni berat tongkol basah sebagai hasil produksi jagung pulut (Tabel 1), namun belum terindikasi secara signifikan pada panjang dan diameter tongkol (Gambar 4 dan Gambar 5). Hasil yang diperoleh belum maksimal dan kurang dari panjang tongkol jagung 
pulut varietas uri $\pm 16 \mathrm{~cm}$ (Iriayani et al., 2016). Hal ini disebabkan oleh masih kurangnya pasokan nitrogen dalam sistem budidaya. Unsur hara nitrogen merupakan komponen utama dalam proses sintesa protein mempengaruhi ukuran tongkol, baik diameter atau panjang tongkol (Saroni et al., 2016). Sebagaimana diketahui bahwa sumber nitrogen dalam budidaya ini hanya berasal dari pangkasan gamal dan selury hasil fermentasi feces kambing. Sistem allaey cropping membutuhkan waktu yang lebih lama untuk memberikan dampak langsung pada tanaman, karena efek secara langsung dimulai dari perbaikan kesuburan lahan. Walaupun demikian sistem alley cropping sudah memberikan dampak secara signifikan terhadap hasil produksi jagung pulut segar. Ini memberikan indikasi positif produksi pangan yang lebih sehat. Meskipun membutuhkan waktu untuk memberikan dampak secara nyata, akan tetapi hasil penelitian ini membuktikan bahwa sistem alley cropping sangat dibutuhkan dalam budidaya jagung di lahan kering miring, dimana konservasi merupakan faktor penting yang harus diutamakan.

\section{KESIMPULAN}

Sistem alley croping dan sistem agrosilvopastura secara signifikan pada awal penerapannya belum mampu memenuhi kebutuhan nitrogen tanaman jagung dalam fase pertumbuhan maupun fase produksi. Penerapan kedua sistem budidaya ini membutuhkan waktu untuk memberikan dampak secara signifikan tanpa penambahan sumber nitrogen berupa pupuk kimia.

\section{DAFTAR PUSTAKA}

Efendi, R. (2009). Mempertahankan dan meningkatkan produktivitas lahan kering dan produksi jagung dengan sistem penyiapan lahan konservasi. Prosiding Seminar Nasional Serealia, 978-979.

Iriayani, N., Takdir, A., Isnaeni, M., Budisantoso, S., M.Yasin, Rahma, A., \& Azrai, M. (2016). 023.-Jagung-Pulut-URI-1.pdf (p. 1). Badan Penelitin dan Pengembangan Pertanian. http://pvtpp.setjen.pertanian.go.id/cms/wp-content/uploads/2016/09/023.-Jagung-PulutURI-1.pdf

Lucila Lapar, M. A., Pandey, S., \& Waibel IRRI, H. (1999). Adoption of Contour Hedgerows by Upland Farmers in the Philippines: An Economic Analysis. IRRI.

Manyong, V. M., Sanginga, P. C., Vissoh, P., \& Honlonkou, A. N. (1999). Mucuna fallow diffusion in southern Benin. International Institute of Tropical Agriculture, 1-23. 
Nurmiaty, Baja, S., Arif, S., Ridwan, A., Rahmad, D., \& Sukmawati. (2019). Developing Agricultural Land Geospatial Information in Supporting Regional Food Resilience. IOP Conference Series: Earth and Environmental Science, 279(1). https://doi.org/10.1088/1755$1315 / 279 / 1 / 012005$

Ogunlana, E. A., Noomhorm, A., \& Silakul, T. (2010). Alley farming in Thailand. Sustainability, 2(8), 2523-2540. https://doi.org/10.3390/su2082523

Preston, T. (2005). Biodigesters in ecological farming systems. LEISA Magazine, 8-12. http://www.agriculturesnetwork.org/magazines/global/energy-on-the-farm/biodigesters-inecological-farming-systems

Rahma, S. (2018). Respon genotipe jagung pulut lokal pada pemupukan nitrogen. UNHAS. http://digilib.unhas.ac.id/uploaded_files/temporary/DigitalCollection/OGU2Y2Y5ZDNkMj Y0OTBhMzkyMjllYWU3NzIxNzdlOWMwZTE2YWZhNg==.pdf

Saroni, Y., Mulyono, \& Haryono. (2016). Uji Efekivitas tepung bulu ayam sebagai sumber nirogen pada pertumbuhan dan hasil tanaman jagung. Naskah Publikasi. Fakultas Pertanian UMY. Yogyakarta.

Seiter, S., William, R. D., \& Hibbs, D. E. (1999). Crop yield and tree-leaf production in three planting patterns of temperate-zone alley cropping in Oregon, USA. Agroforestry Systems, 46(3), 273-288. https://doi.org/10.1023/A:1006204018212

Thy, S. (2007). Management and utilization of biodigesters in integrated farming systems. 1-18.

Tripathi, B., \& Psychas, P. (1992). Core Course in Alley Farming (Vol. 1).

Vittal, K. P. R., Singh, H. P., Prasad, J. V. N. S., Rao, K. V, Victor, U. S., Sankar, G. R. M., Ravindra, G., Singh, G., \& Samra, J. S. (2003). Bio-Diverse Farming System Models for DrylandAgriculture:an AICRPDA contribution. 58. http://www.crida.in/AICRPDA/BioDiverse.pdf

Wolz, K. J., \& Delucia, E. H. (2018). Agriculture , Ecosystems and Environment Alley cropping : Global patterns of species composition and function. Agriculture, Ecosystems and Environment, 252(April 2017), 61-68. https://doi.org/10.1016/j.agee.2017.10.005 